\title{
Reflections on the Quantity Theory
}

Pigou in 1917 and Pareto in 1920-1921

\section{Michael McLure}

\section{CpenEdition}

\section{Journals}

Electronic version

URL: http://journals.openedition.org/ress/2571

DOI: $10.4000 /$ ress.2571

ISSN: $1663-4446$

\section{Publisher}

Librairie Droz

\section{Printed version}

Date of publication: 15 December 2013

Number of pages: 173-192

ISBN: 978-2-600-01805-0

ISSN: 0048-8046

\section{Electronic reference}

Michael McLure, «Reflections on the Quantity Theory », Revue européenne des sciences sociales [Online], 51-2 | 2013, Online since 01 January 2017, connection on 20 March 2020. URL : http:// journals.openedition.org/ress/2571 ; DOI : https://doi.org/10.4000/ress.2571 


\title{
REFLECTIONS ON THE QUANTITY THEORY PIGOU IN 1917 AND PARETO IN 1920-192I
}

\author{
MICHAEL MCLURE \\ University of Western Australia \\ mmclure@biz.uwa.edu.au
}

\begin{abstract}
In 1917, Pigou published his classic article on "The Value of Money" in the Quarterly Journal of Economics. In 1920-1921, Pareto wrote a manuscript on monetary theory, "Note Critiche di Teoria Monetaria", but it was not published until 2005 when some fragments of that manuscript were located by Fiorenzo Mornati. In both these papers the authors reflected on the quantity theory of money and both established the conditions that must be met for the theory to hold. Yet the rhetoric of Pigou in light of his analysis was very moderate, cautious and broadly supportive of the theory; whereas the rhetoric of Pareto in light of his analysis was far more direct, unequivocal and critical of the theory. In this study the analysis of Pigou and Pareto is compared and that analysis is used to explain the difference in their rhetoric pertaining to the quantity theory. It is concluded that this case is illustrative of a more general difference between Cambridge and Lausanne during the second generation of these two respective "schools" of thought.
\end{abstract}

Keywords: Vilfredo Pareto, Arthur Pigou, quantity theory.

Résumé. En 1917, Pigou fait paraître son fameux article "The Value of Money" dans le Quarterly Journal of Economics. En 1920-1921, Pareto rédige de son côté un manuscrit sur la théorie monétaire, "Note Critiche di Teoria Monetaria", qui ne sera publié qu'en 2005 à l'occasion de la découverte de quelques-uns de ses fragments par Fiorenzo Mornati. Dans chacun de ces textes, les auteurs examinent la théorie quantitative de la monnaie et entreprennent d'établir les conditions requises pour que cette dernière puisse se vérifier dans les faits. Cependant, alors que la rhétorique de Pigou, à la lumière de son analyse, reste très modérée, prudente et vise globalement à soutenir ladite théorie, celle de Pareto s'avère, quant à elle, beaucoup plus directe, non-équivoque et critique vis-à-vis d'elle. Dans cette étude, les analyses de Pigou et Pareto sont comparées l'une à l'autre de manière à expliquer les fondements de cette différence rhétorique en relation avec la théorie quantative. En conclusion, il apparaît qu'une telle différence est exemplaire d'une divergence plus générale entre les écoles de Cambridge et de Lausanne, manifeste pendant la seconde generation de ces "écoles" de pensée respectives.

Mots-clés: Vilfredo Pareto, Arthur Pigou, théorie quantitative. 
The names Pareto and Pigou are primarily united by their legacies in welfare economics, though the differences between the two scholars in this field are so significant that many, such as David Collard (20I I), differentiate Paretian welfare economics from Pigouvian welfare economics. Indeed, the contrasts, and similarities, between Pareto and Pigou over aspects of welfare economics and income distribution have been the subject of recent studies by the present author (McLure, 2010 and 2013).

For the history of economic ideas, it is also relevant that Pareto and Pigou were representatives of wider bodies of mainstream economic thought, with Pareto the second generation leader of the "Lausanne School" and Pigou the second generation leader of the "Cambridge School". Of course, these schools have been contrasted at an even more general level, with Lausanne economics being primarily associated with Walrasian general equilibrium and Cambridge school's economics being primarily associated with Marshallian partial equilibrium (Hicks, 1946; De Vroey, 1999; Donzelli, 2008). But within each of these two schools the relationship between money and the real economy was also of considerable importance. The Cambridge school's legacy in monetary economics is recognised as an episode of the first order of importance to the history of economics, with the subject well studied by monetary economists and historians of economics (Bridel, 1987). The Lausanne school's legacy in this area has been less influential, but is still of considerable importance. For example, by the I930s the originality of Walras's approach was highlighted to the English speaking world by Arthur Marget (1931; 1935), was revived and critically considered by Don Patinkin (1965) and the relationship between money and Lausanne general equilibrium in the works of Walras and Pareto has been historically investigated by Pascal Bridel (1997; 2000).

The purpose of this paper is to extend the comparison and contrast of the work of Pareto and Pigou beyond the field of strict welfare economics and income distribution to a core issue in monetary theory: the validity of the quantity theory of money and the mechanisms for expressing that theory. The scope of the study is limited to near contemporary papers: Pigou's influential "The Value of Money" (Pigou, I917), which provides the first formalisation of 
the Cambridge equation for the demand for money in reaction to the quantity theory of money in its Fisherian form; and Pareto's manuscript "Note Critiche di Teoria Monetaria" (Pareto, 2005), which was drafted, but not published, in 1920I92 I as a criticism of the quantity theory of money. ${ }^{1}$

\section{I.PIGOU'S ILLUSTRATION OF THE QUANTITY THEORY}

Arthur Cecil Pigou formally introduced, for the first time (Collard, 2002, p.xxv), the "Cambridge equation" for the demand for real cash balances. He did so in a form that could be readily reconciled with the Fisher exchange equation, and the associated quantity theory of money; and yet provide the apparatus for illustrating that the power of a unit of currency to purchase real goods changes in response to factors other than the quantity of money.

Given the purpose of this paper, it is useful to work backwards from the Fisher equation to highlight the difference between Pigou's approach and the standard presentation of the quantity theory of money. The simplified Fisher equation shows that the product of the quantity of money in terms of units of legal tender (M) and the velocity of circulation for money $(V)$ is equal to the product of the nominal price level $\left(\mathrm{P}^{\mathrm{n}}\right)$ and an index of the volume of transaction $(\mathrm{T})$ :

$$
\mathrm{MV}=\mathrm{P}^{\mathrm{n}} \mathrm{T}
$$

But Pigou's notion of price does not concern the nominal price level $\left(\mathrm{P}^{\mathrm{n}}\right)$; rather, he treats the real price of money as the quantity of wheat that a unit of legal tender can purchase $\left(\mathrm{P}^{\mathrm{w}}\right)$. In other words, wheat is the numéraire by which value within the real economy is measured, and $\left(\mathrm{P}^{\mathrm{w}}\right)$ is the purchasing power of money, as represented by the quantity of the numéraire that a unit of legal tender can command. Consequently, Pigou's notion of price is the inverse of Fisher's, with $\mathrm{P}^{\mathrm{w}}=\mathrm{I} / \mathrm{P}^{\mathrm{n}}$. Pigou also presents the real price of money as the dependent variable. Consequently, the Fisherian equivalent of the Pigouvian notion of the purchasing power of a unit of legal tender is:

$$
P^{w}=\frac{T}{M V}
$$

I Fragments of Pareto's manuscript were discovered in the University of Lausanne archives by Fiorenzo Mornati, who published them in the final volume of Pareto's Opera Omnia in 2005. 
But Pigou's basic contention is that $\mathrm{P}^{\mathrm{w}}$ depends on the demand for real balances, where real balances are titles to legal tender (legal tender, deposits and notes issued by banks) which are measured by the product of: total resources enjoyed by the community at any given moment, expressed in terms of the numéraire good wheat, $\left(\mathrm{R}^{\mathrm{w}}\right)$; and the proportion of those real resources that the community wishes to hold as titles to legal tender (k). Consequently, Pigou specified the real price of a unit of legal tender as:

$$
P^{w}=\frac{k R^{w}}{M}
$$

But Pigou also demonstrates the equivalence of his approach with that of Fisher by suggesting that the right hand side of equation (2), and the right side of equation (3), both represent the value of real balances. This is because the value of real balances, $\left(\mathrm{kR}^{\mathrm{w}}\right)$, is the equivalent of the ratio of $\mathrm{T}$ to $V$ because the proportion of real resources that the community holds as titles to legal tender $(\mathrm{k})$ is the inverse of the velocity of circulation ${ }^{2}(V)$ and transactions $(T)$ are the sum of real quantities of goods weighted by real value (i.e. the quantity of each good is weighted in the transaction index by the quantity of the numéraire good wheat that it could purchase). When equations (2) and (3) are expressed as percentage changes, and the value of the $T$ to $V$ ratio in equation (2) is constant between periods, and the real balances $k R^{w}$ in equation (3) is constant between periods; and the quantity theory emerges.

$$
\% \Delta \mathrm{P}^{\mathrm{w}} \approx-\% \Delta \mathrm{M}
$$

That is, the relative change in the value of a unit of money is negatively related to the relative change in the quantity of money when: the value of real cash balances $\mathrm{kR}^{\mathrm{w}}$ is constant between periods-i.e. when equation (4) is derived from equation (3) -; or, to say the same in another way, the ratio $T / V$ is constant between periods-i.e. when deriving equation (4) from equation (2). 


\section{PARETO'S ILLUSTRATION OF THE QUANTITY THEORY}

The form of Vilfredo Pareto's method of formalising the quantity theory is most closely linked to the Fisher equation, though it is unclear if Pareto had read Fisher's work on this subject and his inspiration appears to be Walras's early work on monetary theory (McLure, 20I2). ${ }^{3}$ The similarity is due to Pareto, like Fisher, setting his equation in terms of nominal prices. The difference is that Pareto isolates the transaction price for the numéraire good from that of the transaction prices for all other goods. As a consequence, Pigou's focus on the purchasing power of money, and its relationship to the numéraire (wheat in Pigou's analysis), is also evident from Pareto's money equation.

Pareto starts his monetary analysis in his "Note Critiche di Teoria Monetaria" (2005[1920-192I]) by attempting to derive the value of transactions from the following Walrasian equation of exchange of goods and productive services for an individual. However, as already indicated, he does so by isolating the numéraire good from other economic goods:

$$
a_{0} p_{0}+\sum_{\tau=1}^{\mathrm{T}}\left(a_{\tau} p_{\tau}\right)=0
$$

$a_{0} \quad$ quantity of the numéraire good

$p_{0} \quad$ nominal price of the numéraire good

$a_{\tau} \quad$ quantities exchanged of goods and services $1,2 \ldots T$

$P_{\tau} \quad$ nominal exchange prices of goods and services $1,2 \ldots T$

To derive the value of transactions for the economy as a whole, Pareto: manipulates equation (5) to create an equality that shows the value of good acquired on the left hand side and value of goods supplied on the right hand side; aggregates the algebraically rearranged equations (5) for all individual entities in the economy (such as consumers, producers, savers, capitalists, banks,

3 To date the author has found no reference in Pareto's works to Fisher's classic The Purchasing Power of Money, and it is uncertain if he ever read it. By 1911, Pareto had devoted himself almost entirely to sociology and was, to a considerable extent, isolated from developments in the English speaking world. This is one of the reasons why Mornati's discovery of fragments of Pareto's unpublished 1920-1921 manuscript is so important for scholars investigating the development of Pareto's ideas on economic matters. 
government entities); and, since economic goods represented by variable a are recorded twice (once as a receipt and again as a payment), the value of transactions is equal half the sum of the aggregate value of economic goods received plus half the sum of the aggregate value of economic goods supplied.

For consistency of comparison with Fisher and Pigou in this paper, it is assumed here that $\mathrm{T}$ indicates a transaction (i.e. $1 / 2 \mathrm{a}$ in Pareto's own equations) and the numéraire good is taken to be wheat. On that basis, Pareto's estimate of the value of transactions may be represented by:

$$
T^{w} p^{w}+T^{o} P^{o}
$$

Tw aggregate quantity of wheat transactions in a period.

$p^{w}$ nominal price of wheat during the period.

$T^{0}$ vector of aggregate transaction quantities for all economic goods other than wheat.

po vector of nominal transaction prices for all economic goods other than wheat.

Pareto then posits that the quantity of money is obtained by multiplying the nominal value of transactions, given in a reduced form by equation (6) above, by the proportion of the total value of transactions that are actually undertaken with money $(\alpha)$ and dividing by a coefficient that represents the velocity of circulation $(V)$.

$$
M=\frac{\alpha\left(T^{w} p^{w}+T^{o} P^{o}\right)}{V}
$$

Prima facie, Pareto's equation is very close to the Fisher equation, with the sum of $\mathrm{T}^{\mathrm{w}} \mathrm{p}^{\mathrm{w}}$ and $\mathrm{T}^{\mathrm{p}} \mathrm{P}$ e equating to the Fisherian notion of PT, with $\mathrm{M}$ and $V$ having the same meaning in Fishers and Pareto's equations. ${ }^{4}$ The only difference being that Pareto introduced the coefficient $\alpha$, which has a superficial similarity with the $\mathrm{k}$ from Pigou's Cambridge equation. Pigou's $\mathrm{k}$ is the inverse of Fisher's $V$. Consequently, if Pareto's $\alpha$ was also the inverse of velocity of circulation, his

4 Pareto actually used the Greek letter $\sigma$, for the quantity of money $M$, and lower case $v$ for the velocity of circulation $V$; but for convenience of comparison with Pigou and Fisher, and to avoid the confusion associated with Pareto assigning two different meanings to $v$ in his manuscript (velocity in the context of the exchange equation, and as a real transaction coefficient when investigating change between periods), the letters $M$ and $V$ have been utilised in this paper when discussing Pareto's equations. 
equation would be over-determined with velocity included in the denominator and the inverse of velicity included in the numerator. But what Pareto had in mind here for $\alpha$ is the proportion of all exchanges that are not mediated by means of money in any way (so no provision needs to be made for money to settle such exchanges). The gifting of presents is one example, unremunerated activities could be another. Specifically, Pareto explicitly recognises that only a proportion of all transactions influence the quantity of money.

To illustrate the quantity theory of money, Pareto undertook analysis of the change in the quantity of money, prices and transactions between two periods. To facilitate his investigation of that relationship, Pareto introduced two relative coefficients: (i) a real transaction coefficient labelled (v), which is the ratio of (value weighted) output in year $n$ to (value weighted) output in year $n+r$; and (ii) a nominal price coefficient labelled $(\mu)$, which is the ratio of nominal prices in year $n$ to year $n+$ I. Pareto does not label $v$ and $\mu$, he just refers to them a coefficients. Nevertheless, he gives illustrative examples which make their respective meaning clear by noting that there is: no growth or contraction in the real economy when $v=\mathrm{I}$; the real economy grows when $v<\mathrm{I}$; and, the real economy contracts when $v>$ I. Similarly, again between the same periods, there is no change in nominal prices when $\mu=\mathrm{I}$; nominal prices rise when $\mu<\mathrm{I}$; and nominal prices fall when $\mu>\mathrm{I}$. Consequently, when $g$ indicates the rate of growth in the real economy and $\pi$ indicates the rate of price inflation, his coefficients can be labelled and defined as:

$$
\begin{array}{ll}
v, \text { a "real transaction" coefficient: } & v=\frac{1}{1+g} \\
\mu, \text { a "nominal price" coefficient: } & \mu=\frac{1}{1+\pi}
\end{array}
$$

Pareto's illustration of the relationship between these coefficients and monetary theory is undertaken with direct reference to equation (5), but the coefficients may be inserted directly into equation (7) to give the quantity of money in period $n+I$. 


$$
M_{n+1}=\frac{\alpha_{n}\left\{\frac{T_{n}^{w} p_{n}^{w}}{v \mu}+\frac{T_{n}^{o} P_{n}^{o}}{v \mu}\right\}}{V_{n}}
$$

The bracketed term of the numerator in equation (8) represents the nominal value of wheat transactions plus the nominal value of all other transactions for the period $n+r$. The proportion of total transactions facilitated through the payment of money, $\alpha$; and the velocity of circulation, $V$, both remain unchanged in period n+I relative to the previous period, n. Consequently, when Pareto analyses "between period" movements in the quantity of money he deliberately sets aside variations in the proportion of transactions undertaken with money and variations in the velocity of circulation of money. Equation (8) may be simplified to the form shown below, which Pareto presented in his manuscript:

$$
M_{n+1}=\frac{M_{n}}{v \mu}
$$

For comparison with Pigou's equation and its relation to the quantity theory of money, it is useful to consider the relationship evident from Pareto's equations concerning the rate of change between periods in the: quantity of wheat that can be purchased with a unit of legal tender (i.e. the change in Pigou's Pw); and the quantity of money (M). ${ }^{5}$ The underlying relationship between these "between period" rates of change can be made explicit through the introduction of logarithms and with due regard to the earlier noted definitions of Pareto's real transactions and nominal price coefficients. ${ }^{6}$

$$
\begin{gathered}
\% \Delta P^{w}=\left(\frac{\mu}{v}-1\right) \cdot 100 \\
\approx\{\log (1+g)-\log (1+\pi)\} \cdot 100 \\
\approx(g-\pi) \cdot 100
\end{gathered}
$$

5 The percentage change in the quantity of wheat that can be purchased with one unit of currency [equation ( $10 \mathrm{a})$ ] depends on the relation $P_{n}^{w}=T_{n}^{w} / p_{n}^{w}$ in period $n$ and relation $P_{n+1}^{w}=\left(T_{n}^{w} \mu\right) /\left(p_{n}^{w} v\right)$ in period $n+1$, which are derived from equations (7) and (8). The percentage change in the quantity of money [equation ( $\mathrm{I}$ la)] is derived directly from equation (9).

6 I thank Ken Clements for suggesting the use of logarithms to relate Pareto's analysis of the rate of monetary emissions to $g$ and $\pi$. 


$$
\begin{gathered}
\% \Delta M=\left(\frac{1}{v \mu}-1\right) \cdot 100 \\
\approx\{\log (1+g)-\log (1+\pi)\} \cdot 100 \\
\approx(g+\pi) \cdot 100
\end{gathered}
$$

Consequently, the quantity theory of money holds when the real growth rate, $g$, is zero, which means that Pareto's real transaction coefficient must be one, i.e. $v=\mathrm{I}$. In that case, equations ( $\mathrm{ob}$ ) and ( $\mathrm{I} \mathrm{Ib})$ approximate to $-\pi \mathrm{I} \circ \mathrm{o}$ (percentage change in the purchasing power of money) and $+\pi$ ioo (percentage change in the rate of monetary emissions) respectively, which is the quantity theory result represented by equation (4) from Pigou's analysis? It may be concluded, therefore, that equation (4) holds within Pareto's framing of monetary theory on the condition that Pareto's real transaction coefficient is I, which means that real growth must be zero (for whatever reason).

\section{PIGOU AND PARETO: THEIR CONCERNS WITH THE "QUANTITY THEORY”}

Interestingly, both Pigou and Pareto used their monetary equations of exchange to point to circumstances when the conditions necessary for the quantity theory of money to hold are not met, but they focused on different factors when considering violations of those considerations. Pigou was primarily concerned with the effect that a variation in the proportion of national resources held as real balances, and the implications of that for the inverse nexus between the purchasing power of a unit of money and the quantity of money. Conversely, Pareto's equations suggest that the breakdown in the quantity theory is primarily due to the economic interdependence between the level of real transactions and the quantity of money, with the real transaction coefficient applying to activity in the real economy (transactions) and the quantity of money.

7 Alternatively, if Pareto's coefficients are retained, when $v=\mid$ the same result is obtained because equations (IOa) and (I la) reduce respectively to: $\% \Delta \mathrm{P}^{w}=(\mu-1) 100$ and $\% \Delta M=\{(\mid / \mu)-1\} 100$. 
Pigou's equation (3) is only a simplification of his approach: it provides an indication of the demand for "real cash balances", where the real economy is scaled by $k$ to indicate the proportion of real balances demanded, but recognises that only a proportion of this constitutes the demand for real cash balances because of the way that the banking system works. Specifically, Pigou resorts to the notion of a representative person who holds real balances in two proportions: one proportion being the share of real balances held as titles to legal tender and held in notes and coins, (c); and another proportion being the share of real balances held as bank balances by bank customers (I-C). As bank deposits are the source of loan funds, titles to legal tender only contribute to the demand for money in terms of the proportion of customers' balances that banks choose to retain as legal tender against the balances held by customers, which is designated by the letter h. As a result, Pigou's approach represented by equation (3) is extended to equation (I2):

$$
P^{w}=\frac{k\{c+h(1-c)\} R}{M}
$$

When $R$ is assumed to be independent of the quantity of money, Pigou's approach suggests that the quantity theory of money requires the relation $\mathrm{k}\{\mathrm{c}+\mathrm{h}(\mathrm{I}-\mathrm{c})\}$ to be constant between periods. Consequently, if the quantity of money is unchanged, the real value of money (the amount of wheat that a unit of currency can purchase) varies in response to variations in: the proportion of real balances, (k); the proportion of real balances held as legal tender (c), such as notes and coins, and bank deposits, the variable (I-c); and/or the proportion of deposits that banks retain as legal tender against the balances held by bank customers, (h).

Pigou (2002 [1917], p.203-204) also indicates that $k$ varies in response to changes in: the convenience individuals gain from holding real balances; the opportunity cost of holding such balances, such as forgone income from not investing in the production of future commodities; and forgone satisfaction from not undertaking current consumption. For example, periodic fluctuations in "the expected fruitfulness of industrial activity" may cause $k$ to change. Expectations are important in that regard: expectations of deflation increase 
people's desire to hold money and expectations of inflation decrease people's desire to hold money, other things being equal.

The share of real balances held in notes and coins (c), or otherwise (I-c), also alters with the distribution of income because "the rich scarcely pay for anything in coin" (Pigou, 2002 [1917], p.207). This also implies that a general increase in real per capita income increases the proportion of real balances held in bank deposits, even in the absence of a change in the distribution of income. Related to this is the extent of the banking system. More generally the share of real balances held as bank deposits increases as the extent of the banking system grows, such was when cheque facilities are increased or the period of credit offered by shopkeepers and traders is increased.

The deposits that banks retain as cash against their customers balances (h) will also vary in response to a number of economic factors similar to those that affect the demand for real balances k. Factors specific to the bank sector include internal organisation of banks, including cross bank arrangements such as clearing houses, the proportions in which bank liabilities are held across different types of accounts, with reserves associated with accounts that place cash in the hands of foreign depositors (who may need to withdraw legal tender for currency conversions) and the general public (savings accounts), which is sometimes higher than in the case of operating or other accounts (from which withdrawals are facilitated by cheques, bank notes or other instruments designed to transfer funds from one account to another). Of course, (h) must also be large enough to account for changes in sentiment about the viability of the banking system in the face of panic.

To the extent that changes in the general resources of the community, $R$, are considered, it is in the context that it affects $k$, with the increase in $R$ from industrial expansion increasing the share of resources held in real balances because the poor cannot afford the luxury of money in hand. In that case: "the same cause that brought about an increase in $\mathrm{R}$, will have affected the variable $\mathrm{k}$ in the same sense" (Pigou, 2002 [1917], p.215). 
The end result of Pigou's analysis is that it does not support a very strict application of the quantity theory as the factors that he associated with a potential breakdown of the quantity theory (primarily variations in k, c and h) are extensive. As David Collard has observed, Pigou's I9I7 article demonstrates that:

[...] without simplifying assumptions, the demand for real cash balances will not in general be constant and the dichotomy between the real and monetary sectors disappears (Collard, 20II, p.23).

Pareto also concludes that there are no real and monetary sectors that are not related. His analysis does not support the dichotomy between the real and monetary sectors as there is no a priori reason to expect his real transaction coefficient to be I, because the real and monetary sectors are interdependent with each other. Indeed, he rejected the quantity theory result because he regarded its validity as being predicated upon the real value of transactions being unrelated to, and independent of, the quantity of money, which he regarded as erroneous.

\section{WHY IS THE RHETORIC OF PIGOU AND PARETO ON THE "QUANTITY THEORY” SO DIFFERENT?}

Notwithstanding the fact that both Pigou and Pareto spilt a lot of ink writing on the conditions that must be met for the quantity theory to hold, and made it quite clear that those conditions often won't be met, their rhetoric when drawing conclusions from their analysis is very different. This is evident from the following quotations:

Pigou on the "quantity theory": At the outset I insist that, tho the machinery that I shall suggest in the following pages is quite different from that elaborated by Professor Irving Fisher in his admirable Purchasing Power of Money, and, as I think, more convenient, I am not in any sense an "opponent" of the "quantity theory" or a hostile critic of Professor Fisher's lucid analysis (Pigou, 2002 [1917], p.199).

Pareto on the "quantity theory": One has a theory, complete, simple, beautiful. A shame it does not accord too much with the facts. [...] The reality is that there is only a relationship of interdependence and to know the particulars [of the relationship between the quantity of money and prices] considerations other than monetary circulation and prices are needed (Pareto, 2005 [1920-1921], p.264). 
There are three substantive reasons for this difference in rhetoric.

The first substantive reason is that Pigou and Pareto consider the quantity theory from two different points of reference. Pigou's focus contrasts two distinct "machineries" of monetary theory that may be used to illustrate the quantity theory, i.e. the Fisherian equation of exchange and his alternative demand for real cash balances equation. The proposition that changes in the quantity of money are neutral to the real economy is secondary to the basic question of how the machinery of monetary theory can best establish the conditions necessary for that theory to be met and the identification of influences that may act to prevent those conditions from being met.

The "quantity theory" is often defended and opposed as tho it were a definite set of propositions that must be either true or false. But in fact the formulae employed in the exposition of that theory are merely devices for enabling us to bring together in an orderly way the principle causes by which the value of money (Pigou, 2002 [1917], p.199).

In contrast, Pareto considered the machinery of monetary theory as nothing more than a device to identify the conditions necessary for changes in the quantity of money to fully explain nominal price levels, without altering relative prices; ${ }^{8}$ and remain neutral with respect to activity in the real economy. His formulation of monetary exchange is essentially Fisherian, but Pareto was not, like Pigou, responding to Fisher's careful analysis of the quantity theory. Instead, he was, to paraphrase Pigou, setting out to investigate the quantity theory as a "definite set of propositions that must be either true or false".

The second substantive influence on Pigou's and Pareto's rhetoric is the result of an important difference in analysis within their equations that define monetary theory. Pigou generally takes the real sector $R$ as given and examines monetary questions with respect to changes in the particular portion of the

8 In his manuscript, Pareto extends his analysis of monetary exchange from that presented in this paper to one in which two categories of transaction are considered beyond the numéraire good: a category of commodities whose prices do not change (or change modestly) in the presence of a change in the quantity of money; and a third set of commodities whose prices change more than the general price change. That analysis, which is predicated on the view that real-monetary interdependences are not uniform across all commodities, is overviewed in McLure (2012). 
real economy (the portion that corresponds to real balances). When variations in activity in the real sector are considered, it is in the context of what that means for changes in the proportion of resources retained in real balances. Pareto's analysis of the monetary question, however, sets variations in proportions aside (i.e. he formally recognised that proportion of real transactions undertaken with money will vary, but, for analytical purposes, he treated that proportion as if they it was constant). Instead, his focus is overwhelmingly on variations in the level of real economic activity, which he considered in relation to variations in nominal prices and the quantity of money.

The critical point here is that Pareto's analysis of variations in real activity and variations in nominal prices do not follow any causal direction. Moreover, he saw no general regularity associated with the interdependence between the real and monetary sectors because growth in the real transactions could be concurrent with rising prices; falling prices; unchanged prices; or all three at the same time (i.e. the price of some goods may rise, others may fall while and others are left unchanged). The same can be observed in the case of a decline in the real economy. As such, he held little hope that a formalised mechanism could identify systematic and uniform relations between the real and monetary sectors that could be confirmed empirically. The formal mechanism that he employed only served to highlight what is missed by the quantity theory. As a consequence, Pareto did not consider that a formal mechanism, such as a monetary exchange equation, had a significant place in monetary theory.

Pigou overcomes the hurdle that Pareto refuses to jump by treating the real sector, $\mathrm{R}$ in his equation, as essentially exogenous, rendering money as neutral to the real economy. As such, instead of emphasising interdependence between the monetary and real sectors and a resulting independency between changes in prices, real transactions and the quantity of money, he is effectively imposing a specific direction of causation, with changes in the real sector flowing through to monetary arrangements and cash balances. The role for interdependencies is largely limited to the quantity of money, price levels and proportions of real resources related to cash balances $k, c$ and h. On that basis, the interdependence between a change in quantity of money and a change 
in the real sector is set aside, implicitly relegated to a second order issue. If that is a legitimate theoretical framing, then the mechanism of monetary theory-associated with equations like Fisher's and Pigou's - does indeed open up the possibility of identifying general, albeit qualified, relations between changes in the quantity of money and the real value of money.

The third reason for the difference in rhetoric between Pareto and Pigou concerns the reason behind Pareto's wish to retain the possibility of nominal price rises $(\mu<\mathrm{I})$ being observed in conjunction with both an increase in real economic activity $(\mathrm{v}<\mathrm{I})$ and a decrease in real economic activity $(\mathrm{v}>\mathrm{I}$ ) under different social circumstances. The reason is related to his conviction that sociological influences, such as the impact of government initiated redistribution in the face of diverse sentiments, impact on the relationship between money and the real economy. In that regard, in his Trattato di Sociologia Generale, Pareto infers that there is interplay between what may be loosely termed fiscal and monetary illusion:

Money is an instrument of exchange and as such is studied by economics. But it is also an instrument for levying taxes without suspicion on the part of the public at large that it is being taxed; and in that connection the study of money belongs to the various branches of sociology (Pareto, 1935 [1916], p.I408, §2016).

He again returns to this issue in his article "Economia Sperimentale", his final article published in the Giornale degli Economisti9 , by drawing attention to Irving Fisher's suggestion, in paragraph 7 of "Some Contributions of the War to our Knowledge of Money and Prices" (2007 [1918], p.258.), that post-Word War I inflation in the wake of the Government issuing vast quantities of bonds during the war was a disguised tax on fixed income bond holders and savers generally. In response, Pareto noted: "if one accepts this point, and it is difficult not to, how can one formulate a theory of money while ignoring its sociological connections?" (Pareto, 2007 [1918], p.315). Pareto was writing during the World War I and he fully appreciated the relationship between a high rate of monetary expansion and

9 The Giornale degli Economisti was, among other things, the journal of Pareto and his school (see McLure, 2007, p.50-84 ). It is also the journal in which almost all of Pareto's original major contributions to economics were first published. 
price inflation in such circumstances. But he also observed the uneven distribution of the relative costs and benefits of inflation on different groups in society, especially when monetary policy is undertaken as a means of enhancing government's funding of public activities. To Pareto, the economic point was that the combined effect of monetary/fiscal transfers should typically result in the "destruction of wealth" (i.e. v > I) because the economic effects of such a policy are not uniformly distributed across all members of a society; but the matter does end there. The sociological point is that such monetary and fiscal policy actions are influenced by variable human sentiment, which falls outside the scope of his strict definition of logical action, and, as such, the expected "economic" destruction of wealth may be either accentuated, avoided or even more than offset by the sociological forces.

In short, when monetary phenomena are influenced by sentiment, and that sentiment acts as a variable force upon human action, Pareto suggests that sociology cannot be ignored. In regard to the equations that Pareto used to interrogate the implications of the quantity theory in his 1920-1921 manuscript, it is the interdependence between the real sector and the monetary sector that opens the door to sociological analysis. More specifically, the range of possible relationships between Pareto's nominal price coefficient, $\mu$, and his real sector coefficient, $v$, is diverse because of the influence of factors that Pareto treated sociologically, such as: the propensity of governing elites, and their supporting economic elites, to use monetary policy to the benefit of rentiers ("timid" economic actors who value long period benefits and seek low but very secure returns) or speculators (risk taking economic actors who act on the potential for a high rate of return in the short period); and the character of the reaction to any consequent redistribution facilitated through monetary policy by subsidized parties (e.g. speculators in periods of rising inflation) and by subsidizing parties (e.g. rentiers in periods of rising inflation). Pareto's Sociologia suggested that the economic consequences of redistribution-whether the effect on the real economy is positive, neutral or negative-implemented through government action, such as monetary, fiscal or trade policy, is related to the character of the prevailing social equilibrium. ${ }^{10}$

I0 Important aspects of Pareto's social equilibrium include the proportions of people with a high propensity for reordering arrangements within society, relative to the proportion of 


\section{CONCLUSION}

At one level, the difference in emphasis by Pigou and Pareto in their analysis of the quantity theory is symptomatic of the broader clash between Cambridge, which emphasised realistic theory that utilises the "other things remain the same" assumption to set aside distracting second order issues, and Lausanne, which emphasises the broad economic system and its various interdependent linkages, including sociological as well as economic interdependencies.

If the influence of sociological forces on monetary policy is set aside completely (i.e. if the interdependent relationship between the real sector and the quantity of money is replaced by a presumption that the demand for real cash balances derive from the given size of the real sector) then it is possible to derive a credible formula that represents the machinery of monetary theory. That theory also lays a foundation for the consideration of the short run and long run implications of monetary theory for prices and the real economy. ${ }^{.1}$ But even in terms of strict economic analysis, Pareto was still less interested than Pigou in subtly assuming "other things being equal". If the quantity theory holds in very strict microeconomic as well as macroeconomic terms, then the relative prices of economic goods should be unchanged if demand and supply conditions are unchanged as the general price level changes in direct proportion to the rate of monetary expansion. That was a sign to the mature Pareto that something was wrong with the theory. The two main problems with the quantity theory to Pareto were the presumption that money is neutral with respect to the real economy, as he saw no grounds for

people with a high propensity to preserve existing arrangements-with the differences in those proportions between the elites and the masses being particularly significant-and the accommodation of rentier and speculator activities by political elites. The Paretian treatment of politically instigated redistribution by fiscal means has been previously investigated in some detail by the present author (McLure, 2007).

II As Thomas Humphrey (2004, p.4) has noted, while Alfred Marshall supported proposition that there is a unidirectional causation between money and prices and that money is neutral with respect to the real economy in the long run, he regarded money as non-neutral with respect to the real economy in the short run. In terms of Pigou's equation Marshall's proposition implies that variation in $k, c$ and $h$ offset each other in the long term and $R$ is not influenced by $M$, whereas in the short run such variations may not offset each other. 
such an assumption, and the emphasis in the theory on a causal relationship running from the quantity of money to prices, as he considered that a relationship of interdependence could be ascertained between the real sector, prices and the quantity of money.

This explains the difference in the force of Pigou's and Pareto's rhetoric when commenting on the conditions they identify for the quantity theory to hold. Pigou accepts that, as a means of approximation, it is reasonable to assume away some difficult problems of interdependence by accepting a casual influence running from the real economy to the value of real cash balances. Pareto, however, was unwilling to impose a direction of causation under any circumstance. Indeed, he appears to search for every possible interdependent relationship to heighten our understanding of the complexity of the relationship between the monetary and real sectors. Overlaying the economics of money with the sociology of money is the obvious example.

In terms of rational history, the fundamental question is whether Pigou's attempt to orient monetary theory around the machinery of an equation that is partial, in that it imposes a casual relationship from the real economic to the demand for real balances, gives a better understanding of the general regularities of the relationship between monetary and real economics than Pareto's perspective, which has the potential to overstate the importance of interdependencies. In terms of a historical reconstruction, this issue may be viewed another way. This is yet another aspect of the relative emphasis in Cambridge on economics that generates "light" (theory) that can create "fruit" (assist policy makers); and the relative emphasis in Lausanne under Pareto's leadership on generating light under which scholars can simply consider the full range of economic and social interdependencies associated with action.

NA. I would like to thank Ken Clements for his very helpful comments on an earlier draft of this paper. 


\section{BIBLIOGRAPHY}

BRIDEL Pascal, 1987, Cambridge Monetary Thought: the Development of SavingsInvestment Analysis from Marshall to Keynes, Basingstoke, Macmillan.

-, 2000, "From Walras's to Pareto's Teachings: the Case of Monetary Theory" in Economia, Sociologia e Politica nell' Opera di Vilfredo Pareto, edited by Corrado Malandrino and Roberto Marchionatti, Florence, Olschki editore, p.123-139.

COLLARD David, 20II, Generations of Economists, London, Routledge.

-, 2002, "Introduction" in A. C. Pigou: Journal Papers 1902-1922, London, Palgrave Macmillan, p.xi-xxxiii.

DE VROEY Michel, 1999, "The Marshallian Market and the Walrasian Economy: Two Incompatible Bedfellows", The Scottish Journal of Political Economy, 46, p.319-338.

DONZELLI Franco, 2008, "Marshall vs Walras: Equilibrium and Disequilibrium", History of Economics Review, 48, Summer, p.I -38.

FISHER Irving, 1913 (1911), The Purchasing Power of Money, its Determination and Relation to Credit, Interest and Crises, New York, Macmillan.

-, 1918 "Some Contributions of the War to Our Knowledge of Money and Prices (abstract)", American Economic Review, 8-I, Supplement, Papers and Proceedings of the Thirtieth Annual Meeting of the American Economic Association, p.257-258.

HICKS John R., 1946, Value and Capital: An Enquiry into some Fundamental Principles of Economic Theory, $2^{\text {nd }}$ edition, Oxford, Oxford University Press.

HUMPHREY Thomas H., 2004, "Alfred Marshall and the Quantity Theory", Federal Reserve Bank of Richmond, Working Paper Series, p.4-10.

MARGET Arthur, 1931, "Léon Walras and the 'Cash-Balance Approach' to the Problem of the Value of Money", Journal of Political Economy, 39-5, p.57I-600.

-, 1935, "The Monetary Aspects of the Walrasian System", Journal of Political Economy, 43-2, p.145-186.

MCLURE Michael, 2007, The Paretian School and Italian Fiscal Sociology, Houndmills, Palgrave Macmillan. 
-, 2010, "Pareto, Pigou and Third-Party Consumption: Divergent Approaches to Welfare Theory with Implications for the Study of Public Finance", European Journal of the History of Economic Thought, 17-4, p.635-657.

-, 2012, "Pareto's Manuscript on Money and the Real Economy", in Vilfredo Pareto: Beyond Disciplnary Boundries, edited by Joseph V. Femia and Alasdair J. Marshall, Franham, Ashgate, p. 177-197.

-, 2013, "A.C. Pigou's Rejection of Pareto's Law", Cambridge Journal of Economics, [print copy, forthcoming, published on line in October 2012]: http://cje.oxfordjournals.org/content/early/2012//0/25/cje.bes045.abstract/ PARETO V.,1935 (1916), The Mind and Society, 4 vols, New York, Harcourt, Brace and Co. -, 2007 (1918), "Experimental Economics" in M.Mclure, The Paretian School and Italian Fiscal Sociology, Houndmills, Palgrave Macmillan, p.195-202 and p.315-316. -, 2005 (1920-1921), Note critiche di teoria monetaria, Euvres complètes, t.XXXII, Genève, Droz, p.259-268.

PIGOU V., 1917, "The Value of Money", Quarterly Journal of Economics, 32, p.38-65; reprinted in A. C. Pigou: Journal Papers 1902-1922, David Collard (ed), London: Palgrave Macmillan. 